\title{
HUBUNGAN PERHATIAN DARI ORANG TUA TERHADAP HASIL BELAJAR SISWA SEKOLAH DASAR
}

\author{
Tio Gusti Satria* \\ Pendidikan Guru Sekolah Dasar, STKIP PGRI Lubuklinggau \\ Jl. Mayor Toha, Air Kuti, Lubuk Linggau Tim. I, Kota Lubuklinggau, Sumatera Selatan, Indonesia \\ *E-mail: satriagustio@gmail.com
}

Artikel diterima: 22 Juli 2020; disetujui: 31 Mei 2021

\begin{abstract}
The purpose of carrying out this research is to determine the relationship between parental attention to the learning outcomes of class II SDIT Raudhatul Jannah Lubuklinggau. The research was using quantitative correlation by the sample of 55 students. Techniques in collecting data using questionnaires and documentation. Techniques in data analysis by applying the formula "product moment correlation" and "double correlation". The results of the study showed a significant relationship between parental attention to learning outcomes. This is evidenced by $\mathrm{r}_{\mathrm{xy}}=0.51542, \mathrm{r}_{\mathrm{xy}}=0.26566$, t-count 3.2944. The conclusion is that there is a significant relationship between parental attention to the learning outcomes of class II SDIT Raudhatul Jannah students
\end{abstract}

Keywords: parents, family; learning outcomes; intelligence; children's education.

\begin{abstract}
Abstrak: Tujuan dari dilaksanakannya penelitian ini adalah mengetahui hubungan antara perhatian orang tua terhadap hasil belajar siswa kelas II SDIT Raudhatul Jannah Lubuklinggau. Penelitian dilakukan dengan jenis korelasi kuantitatif, dan sampel sebanyak 55 siswa. Teknik dalam mengumpulkan data menggunakan teknik kuesioner dan teknik dokumentasi. Teknik dalam analisis data menerapkan rumus "product moment correlation" dan "double correlation". Hasil dari penelitian menunjukkan adanya hubungan yang signifikan antara perhatian orang tua terhadap hasil belajar. Hal ini dibuktikan dari $r_{x y}=0,51542, r_{x y}=0,26566$, t-hitung 3,2944. Simpulannya bahwa terdapat hubungan yang signifikan antara perhatian orang tua terhadap hasil belajar siswa kelas II SDIT Raudhatul Jannah.
\end{abstract}

Kata kunci: orang tua; keluarga; hasil belajar; kecerdasan; pendidikan anak.

\section{PENDAHULUAN}

Pada era milenial sekarang ini, peran orang tua menjadi hal yang diperlukan oleh peserta didik. Perhatian orang tua menjadi salah satu elemen yang tak terpisahkan dari proses belajar peserta didik. Penelitian terdahulu mengungkapkan bahwa perhatian orang tua berpengaruh terhadap prestasi belajar matematika siswa (Ningsih \& Nurrahmah, 2016). Perhatian orang tua juga memiliki hubungan positif dengan motivasi belajar siswa khususnya ketika menyelesaikan tugas belajarnya (Febriany \& Yusri, 2013). Beragam fenomena dalam proses kehidupan peserta 
didik membutuhkan peran orang tua. Misalnya, pada gencarnya kasus narkoba, peran orang tua menjadi penting terutama dalam upaya edukasi preventif sejak dini (Reza, 2016). Lemahnya perhatian dari orang tua terhadap peserta didik mampu memicu timbulnya hal yang negatif terhadap peserta didik.

Permasalahan yang diakibatkan kurangnya perhatian orang tua juga dialami oleh peserta didik di SDIT Raudhatul Jannah Kota Lubuklinggau. Berdasarkan observasi dan wawancara peneliti dari bulan Agustus sampai dengan Desember 2018, ditemukan bahwa 30 orang atau 49\% siswa Kelas II melakukan kesalahan-kesalahan yang dapat mengganggu kegiatan proses pembelajaran. Seperti halnya pada saat jam kedatangan ke sekolah, terdapat peserta didik terlambat datang ke sekolah. Permasalahan lainnya antara lain peserta didik yang tidak menyelesaikan pekerjaan rumah, peralatan belajarnya kurang lengkap, atau peserta didik yang mengenakan atribut sekolah yang tidak rapi.

Pada proses wawancara dengan peserta didik mengenai masalah-masalah yang telah ditemukan, peserta didik mengungkapkan bahwa tindakan indisipliner tersebut erat kaitannya dengan lemah atau kurangnya perhatian orang tua terhadap peserta didik di rumah. Peserta didik mengungkapkan bahwa orang tua kurang peduli dengan diri peserta didik. Lebih lanjut, peserta didik mengungkapkan bahwa saat menghadapi evaluasi orang tua kurang mengingatkan untuk belajar. Bahkan orang tua kurang peduli dengan tugas peserta didik, orang tua jarang menasehati jika mereka melakukan kesalahan, serta orang tua kurang mendukung mereka untuk mengikuti kegiatan-kegiatan di sekolah. Masalah ini diakibatkan karena orang tua sibuk dengan aktifitas atau pekerjaannya. Sehingga mengakibatkan lemah atau kurangnya perhatian orang tua terhadap kegiatan peserta didik.

Orang tua merupakan guru pertama dan yang paling utama bagi anak (Wahy, 2012). Sebagaimana orang tua yang dikatakan sebagai guru pertama bagi anak, karena lewat merekalah anak mendapatkankan pendidikan pertama, dan juga besarnya pengaruh yang diberikan dalam membentuk watak anak (Hasanah, 2016). Sudut pandang psikologi menyatakan bahwa anak yang mendapatkan cinta dan kasih sayang besar dan juga perhatian orang tua selama masa tumbuh kembangnya, ternyata memiliki kecerdasan dan kesehatan lebih baik daripada anak yang tumbuh di sebuah rumah panti dan terpisah dari kedua orang tuanya (Chatib, 2012).

Hasil penelitian terdahulu menunjukkan adanya hubungan signifikan antara perhatian orang tua dengan hasil belajar peserta didik di sekolah dasar (Rismawati, 2015; Soegeng \& Nisa', 2014). Sementara hasil penelitian lainnya menunjukkan bahwa perhatian orang tua tidak berpengaruh terhadap prestasi belajar siswa (Handayani, 2016). Berdasarkan jabaran hasil penelitian di atas, peneliti tertarik melakukan penelitian lanjutan mengenai hubungan antara perhatian dari orang tua terhadap hasil belajar siswa kelas II SDIT Raudhatul Jannah Kota 
Lubuklinggau. Berdasarkan latar belakang yang telah dijabarkan sebelumnya, tujuan dalam penelitian ini adalah untuk mengetahui hubungan antara perhatian orang tua terhadap hasil belajar siswa kelas II SDIT Raudhatul Jannah Kota Lubuklinggau.

\section{METODE}

Penelitian yang bertujuan untuk melihat hubungan antara perhatian orang tua terhadap hasil belajar siswa kelas II SDIT Raudhatul Jannah Kota Lubuklinggau, maka peneliti menggunakan metode korelasi ganda untuk mengetahui adakah hubungan antar variabel.

Populasi pada penelitian ini adalah seluruh peserta didik kelas II SDIT Raudhatul Jannah Kota Lubuklinggau (Lihat Tabel 1). Populasi diambil dari siswa kelas II SDIT Raudhatul Jannah Kota Lubuklinggau yang terdiri dari kelas IIA, IIB, IIC. Pada pemilihan sampel, karena subyek yang akan diteliti kurang dari 100 orang maka akan lebih baik bila diambil semua sebagai sampel (Arikunto, 2010).

Tabel 1. Sebaran Populasi Penelitian

\begin{tabular}{cccc}
\hline \multirow{2}{*}{ Kelas } & \multicolumn{3}{c}{ Kategori } \\
\cline { 2 - 4 } & Perempuan & Laki-Laki & Total \\
\hline IIA & 12 & 5 & 17 \\
IIB & 13 & 6 & 19 \\
IIC & 13 & 6 & 19 \\
\hline
\end{tabular}

Pengukuran perhatian orang tua sebelum digunakan perlu adanya pengujian kelayakan. Ada dua bagian yang pokok berkaitan dengan pengujian suatu instrumen yakni pengujian validitas dan pengujian reliabilitas. Uji validitas pada penelitian yang digunaka adalah rumus Product Moment. Uji reliabilitas melalui rumus Alpha Cronbach. Uji hipotesis dilakukan dengan pengujian korelasi dengan korelasi Product Moment. Hipotesis dinyatakan diterima bila nilai $\mathrm{r}_{\text {hitung }} \geq \mathrm{r}_{\text {tabel }}$ dengan taraf signifikan $5 \%$, dan berlaku sebaliknya.

\section{HASIL DAN PEMBAHASAN}

\section{Uji Validitas Angket}

Penghitungan validitas instrumen ini digunakanlah rumus product moment. Data dianalisis didapatkan berdasarkan hasil uji instrumen berupa angket perhatian orang tua yang berisi 40 butir pernyataan. Hasil uji validitas berdasarkan taraf signifikan 5\% yakni 0,361 $\left(\mathrm{r}_{\text {tabel }}\right)$, diperoleh data bahwa 32 butir soal instrumen memiliki $\mathrm{r}_{\text {hitung }}$ berada pada kisaran $0,36488-0,76593$. Berdasarkan data inilah berarti $r_{\text {hitung }}>r_{\text {tabel }}$ maka instrumen angket 32 yang diuji dapat dikatakan valid, sedangkan 8 butir soal instrumen memiliki $r_{\text {hitung }}$ berada pada 
kisaran kurang dari 0,361 yaitu $-0,1363-0,35647$ maka instrumen angket dianggap tidak valid.

\section{Uji Reabilitas Angket}

Tes reliabilitas angket perhatian dari orang tua dilakukan dengan 32 soal yang telah melewati proses validasi. Tes reliabilitas ditentukan dengan rumus Alpha Cronbach. Tes reliabilitas $\left(r_{11}\right)$ apabila $r_{11} \geq 0,70$, instrumen dikatakan reliabel, bila nilai $r_{11}<0,70$, maka dinyatakan tidak reliabel (tidak dapat dipercaya). Berdasarkan pengujian diperoleh $\mathbf{r}_{11}=0,8943$, berarti 32 item instrumen angket perhatian orang tua dinyatakan telah reliabel.

\section{Uji Hipotesis Hubungan Perhatian dari Orang Tua Terhadap Hasil Belajar Siswa kelas II SDIT Raudhatul Jannah Kota Lubuklinggau}

Uji hipotesis dengan menggunakan rumus Korelasi Product Moment didapatkan hasil $r_{\text {hitung }}(0,51542)>r_{\text {tabel }}(0,349), r_{x y}^{2}(0,26566), t_{\text {hitung }}(3,2944)>t_{\text {tabel }}(2,042)$. Hasil ini menunjukkan bahwa $r_{\text {hitung }}>r_{\text {tabel. }}$ Hal ini menunjukkan bahwa $H_{a 1}$ diterima, dengan kata lain terdapat hubungan perhatian dari orang tua terhadap hasil belajar siswa kelas II SDIT Raudhatul Jannah Kota Lubuklinggau. Perhatian orang tua memiliki sumbangsih sebesar 26,6\% terhadap hasil belajar peserta didik kelas II SDIT Raudhatul Jannah Kota Lubuklinggau.

Perhatian orang tua memiliki hubungan dengan hasil belajar peserta didik. Anak yang mendapatkan cinta dan kasih sayang besar dan juga perhatian orang tua selama masa tumbuh kembangnya, ternyata memiliki kecerdasan dan kesehatan lebih baik daripada anak yang tumbuh terpisah dari kedua orang tuanya (Chatib, 2012). Semakin tingginya perhatian dan kasih sayang dari orang tua maka akan semakin tinggi pula hasil belajar yang diperoleh seorang anak (Endriani, 2018; Febriany \& Yusri, 2013). Perhatian dari orang tua seperti keterlibatan dalam kegiatan pendidikan anak di sekolah dapat diukur berdasarkan karakteristik keluarganya. Kalangan pekerja dan kalangan yang melibatkan ibu dalam bekerja penuh waktu, termasuk ke dalam kriteria kurang memberikan perhatian yang semestinya kepada anak-anak mereka (Rahadian, 2017).

Hasil penelitian menunjukkan adanya hubungan signifikan antara perhatian orang tua terhadap hasil belajar siswa kelas II SDIT Raudhatul Jannah Kota Lubuklinggau. Berdasarkan uraian sebelumnya, maka dapat diketahui perhatian orang tua memiliki hubungan yang kuat dengan hasil belajar siswa. Hal ini selaras dengan penelitian-penelitian sebelumnya yang menunjukkan bahwa siswa yang memiliki perhatian yang besar dari orang tuanya akan memperoleh hasil belajar yang baik (Ningsih \& Nurrahmah, 2016; Rismawati, 2015; Soegeng \& Nisa', 2014). 
Terdapat faktor-faktor yang mempengaruhi keberhasilan dari belajar yakni faktor internal dan faktor eksternal. Hasil belajar tidak ditentukan oleh faktor dari dalam atau dari diri siswa saja, tetapi juga faktor dari luar yang salah satunya dipengaruhi oleh orang tua. Pola asuh orang tua juga akan sangat mempengaruhi pola pikir dan karakter yang muncul pada anak (Hasanah, 2016). Hasil penelitian ini memperkuat penelitian sebelumnya yang menekankan bahwa tidak hanya unsur dari dalam diri siswa yang perlu dikembangkan, seperti faktor internal terkait motivasi, minat belajar, serta kedislipinan belajar, untuk dapat meningkatkan prestasi belajar atau hasil belajar siswa. Kombinasi antara faktor internal dan eksternal juga sangat diperlukan untuk dapat melejitkan potensi siswa khususnya dalam kegiatan belajarnya (Kurniawan \& Wustqa, 2014; Mawarsih \& Hamidi, 2013; Nisa, 2017; Prasojo, 2014).

\section{SIMPULAN DAN SARAN}

\section{Simpulan}

Dari hasil analisis data penelitian dapat disimpulkan bahwa adanya keterkaitan antara perhatian yang diberikan dari orang tua terhadap hasil belajar siswa kelas II SDIT Raudhatul Jannah Kota Lubuklinggau dengan $r_{x y}=0,51542, r^{2}=0,26566$, dan $t_{\text {hitung }}(3,2944)>t_{\text {tabel }}(2,042)$ dengan taraf signifikan sebesar 5\%. Variabel perhatian orang tua memberikan sumbangsih pada variable hasil belajar siswa yakni $26,6 \%$. Hal ini membuktikan bahwa perhatian yang diberikan dari orang tua berpengaruh terhadap hasil belajar siswa

\section{Saran}

Berdasarkan hasil penelitian yang telah dilakukan dan berdasarkan simpulan yang telah dibuat maka terdapat saran. Bagi para orang tua, hendaknya lebih meningkatkan perhatiannya terhadap anak, sehingga anak dapat lebih baik dalam belajarnya. Perhatian dapat berupa aktif dalam memantau efektifitas jam belajar di sekolah. Bagi pihak sekolah terutama guru-guru diharapkan dapat mengembangkan perhatian terhadap siswa di dalam maupun di luar kegiatan pembelajaran. Bagi peneliti berikutnya, untuk meneliti dengan mengeksplorasi penelitian ini dan melibatkan variabel-variabel lainnya yang memiliki keterkaitan dengan faktor hasil belajar.

\section{DAFTAR PUSTAKA}

Arikunto, S. (2010). Metode peneltian. Jakarta: Rineka Cipta.

Chatib, M. (2012). Orangtuanya manusia: Melejitkan potensi dan kecerdasan dengan menghargai fitrah setiap anak. Kaifa.

Endriani, A. (2018). Hubungan Perhatian Orang Tua Dengan Motivasi Belajar Pada Siswa Kelas Viii Smpn 6 Praya Timur Lombok Tengah Tahun Pelajaran 2015/2016. Realita : Jurnal 
Bimbingan Dan Konseling, $\quad$ 1(2). https://ejournal.undikma.ac.id/index.php/realita/article/view/708

Febriany, R., \& Yusri, Y. (2013). Hubungan Perhatian Orangtua Dengan Motivasi Belajar Siswa Dalam Mengerjakan Tugas-Tugas Sekolah. Konselor, 2(1), Article 1. https://doi.org/10.24036/0201321727-0-00

Handayani, S. (2016). Pengaruh Perhatian Orangtua dan Minat Belajar Matematika Terhadap Prestasi Belajar Matematika Siswa. Formatif: Jurnal Ilmiah Pendidikan MIPA, 6(2), Article 2. https://doi.org/10.30998/formatif.v6i2.948

Hasanah, U. (2016). Pola asuh orangtua dalam membentuk karakter anak. Jurnal Elementary, 2(2), 72-82.

Kurniawan, D., \& Wustqa, D. U. (2014). Pengaruh perhatian orangtua, motivasi belajar, dan lingkungan sosial terhadap prestasi belajar matematika siswa SMP. Jurnal Riset Pendidikan Matematika, 1(2), 176-187.

Mawarsih, S. E., \& Hamidi, N. (2013). Pengaruh perhatian orang tua dan motivasi belajar terhadap prestasi belajar siswa sma negeri jumapolo. Jupe-Jurnal Pendidikan Ekonomi, 1(3).

Ningsih, R., \& Nurrahmah, A. (2016). Pengaruh Kemandirian Belajar dan Perhatian Orang Tua Terhadap Prestasi Belajar Matematika. Formatif: Jurnal Ilmiah Pendidikan MIPA, 6(1), Article 1. https://doi.org/10.30998/formatif.v6i1.754

Nisa, A. (2017). Pengaruh perhatian orang tua dan minat belajar siswa terhadap prestasi belajar ilmu pengetahuan sosial. Jurnal Faktor UNINDRA, 2(1), 1-9.

Prasojo, R. J. (2014). Pengaruh Perhatian Orang Tua Dan Kedisiplinan Belajar Terhadap Prestasi Belajar Mata Pelajaran IPS. Ekonomi IKIP Veteran Semarang, 2(1), 37082.

Rahadian, A. S. (2017). Pemenuhan Hak Asi Eksklusif Di Kalangan Ibu Bekerja: Peluang Dan Tantangan (Fulfilling The Right For Exclusive Breastfeeding Among Working Women: Opportunities And Challenges). Jurnal Kependudukan Indonesia, 9(2), 107-116.

Reza, I. F. (2016). Peran Orang Tua Dalam Penanggulangan Penyalahgunaan Narkoba Pada Generasi Muda. Psikis: Jurnal Psikologi Islami, 2(1). http://jurnal.radenfatah.ac.id/index.php/psikis/article/view/1056

Rismawati, K. (2015). Pengaruh Perhatian Orang Tua Dalam Kegiatan Belajar Terhadap Hasil Belajar Siswa Kelas Iv Sekolah Dasar Di Daerah Binaan III Kecamatan Kandangserang Kabupaten Pekalongan [Other, Universitas Negeri Semarang]. http://lib.unnes.ac.id/21086/

Soegeng, A. Y., \& Nisa', Z. (2014). Hubungan Antara Perhatian Orangtua Dan Hasil Belajar Pada Pembelajaran Tematik Integratif Siswa Kelas Iv Sd Negeri Kembangarum 2 Mranggen Demak. Malih Peddas (Majalah Ilmiah Pendidikan Dasar), 4(2), Article 2. https://doi.org/10.26877/malihpeddas.v4i2.533

Wahy, H. (2012). Keluarga sebagai basis pendidikan pertama dan utama. JURNAL ILMIAH DIDAKTIKA: Media Ilmiah Pendidikan Dan Pengajaran, 12(2). 